\title{
PEMPERDAYAAN PETANI PADI UNTUK MENINGKATKAN EKONOMI PERTANIAN MELALUI IMPLEMENTASI MESIN THRESHER DI DESA OPO-OPO SELAMA MASA PANDEMI COVID-19
}

\author{
IImi Rizki Imaduddin"), Raudhatul Jannah²), Irfan Dani ${ }^{3)}$, Hendriano Andika Putra4), \\ Muhammad Imaduddin ${ }^{5)}$, Moch Chotibul Umam ${ }^{6}$, Muhammad Wildan Rifqi ${ }^{7)}$, Leo \\ Andhika $^{8)}$, Misbahul Muniri' \\ 1,2,3,4,5,6,7,8,9)Prodi Teknik Elektro, Universitas Nurul Jadid Paiton Probolinggo \\ 1)ilmirizkiimaduddin@gmail.com, ${ }^{2)}$ maztjen@gmail.com, ${ }^{3)}$ irfandani658@gmail.com , \\ ${ }^{4}$ hendrianoap@gmail.com ${ }^{5}$ muhammadimaduddi2020@gmail.com , \\ 6)Umamchotibul428@gmail.com ,7)Wildanra1@gmail.com , ${ }^{8}$ leorx135@gmail.com , \\ ${ }^{9} \mathrm{mmisbahul819@gmail.com}$
}

\begin{abstract}
Historiartikel
Abstrak

Received:

04 April 2021

Dampak terpuruknya perekonomian masyarakat akibat pandemi COVID-19 terjadi pula pada para petani padi dalam melakukan hasil panennya. Banyak petani tidak mematuhi protokol kesehatan

Accepted: 16 April 2021 COVID-19, dan di samping itu juga banyaknya pekerja dalam melakukan panen membutuhkan biaya yang cukup banyak, dan alat yang digunakan untuk panen padi tersebut masih

Published:

19 April 2021 menggunakan alat yang manual, sehingga membutuhkan waktu yang cukup lama. Oleh karna itu itu metode yang digunakan pada PKM ini meliputi, (i) Penelitian awal, (ii) Perumusan masalah dan tujuan penelitian, (iii) Pengumpulan data, (iv) Perancangan mesin theser padi otomatis, (v) Implementasi hasil rancangan mesin thresher padi otomatis, (vi) Pengujian mesin thresherpadi otomatis, (vii) Kesimpulan, untuk peningkatan ekonomi pertanian yang dapa membuat petani lebih cepat proses panennya dari pada sebelumnya. Hasil dari perontokkan padi 1000-1800 per jam, dengan luas lahan antara $150 \mathrm{~m}^{3}-220 \mathrm{~m}^{3}$, dengan putaran motor $106.2 \mathrm{~S}-35.7 \mathrm{~S}$. Program kemitraan masyarakat (PKM) ini juga sebagai sarana peningkatan ekonomi pertanian di Desa Opo-opo Kecamatan Krejengan Kabupaten Probolinggo di masa pandemi COVID-19.
\end{abstract}

Kata-kata Kunci: pandemi COVID-19, peningkaan ekonomi, mesin thresher otomatis, desa opo-opo. 
Abstract. The impact of the decline in the community's economy due to the COVID-19 pandemic also happened to rice farmers in carrying out their harvests. Many farmers do not comply with the COVID-19 health protocol, and in addition, the large number of workers harvesting requires a lot of money, and the tools used for harvesting rice are still using manual tools, so it takes quite a long time. Therefore, the methods used in this PKM include, (i) initial research, (ii) problem formulation and research objectives, (iii) data collection, (iv) design of an automatic rice theser machine, (v) Implementation of the results of the thresher machine design. automatic rice, (vi) Testing of automatic rice thresher machines, (vii) Conclusion, to increase the agricultural economy which can make farmers harvest faster than before. The yield of rice threshing is 1000-1800 per hour, with a land area of between $150 \mathrm{~m} 3-220 \mathrm{~m} 3$, with a motor rotation of $106.2 \mathrm{~S}-35.7 \mathrm{~S}$. This community partnership program (PKM) is also a means of improving the agricultural economy in Opo-opo Village, Krejengan District, Regency Probolinggo during the Covic-19 pandemic.

Keywords: COVID-19 pandemic, economic enhancement, automatic thresher machine, opo-opo village

\section{PENDAHULUAN}

Indonesia termasuk negara agraris dimana sebagian besar wilayahnya meruapakan wilayah pertanian. Demikian juga mata pencaharian penduduknya sebagaian besar sebagai petani, teruatama petani padi. Hal ini tidak lepas dari makanan pokok masyarakat yaitu beras. Namun ironisnya, walaupun sebagai negara agraris dan makanan pokok rakyat beras, Indonesia masih belum swasembada beras alias masih impor dari negara-negara tetangga seperti Vietnam dan Thailand (Agus Suharmanto, 2016). Desa Opo-opo terletak di Kecamatan Krejengan Kabupaten Probolinggo memiliki luas administrasi $546.132 \mathrm{Ha}$, terdiri dari tujuh dusun. Dengan Luas Pemukiman 34.552 Ha, Luas Persawahan 278.090 Ha, Luas Prasarana Umum lainnya $143.111 \mathrm{Ha}$. Sektor pertanian masih memberikan kontribusi positip terhadap kehidupan masyarakat Desa Opo-opo. Sekalipun kepemilikan lahan pertanian bagi petani yang relatif sempit, yaitu kurang dari 0,5 hektar, namun dengan adanya peningkatan terhadap penguasaan informasi, manajemen dan teknologi melalui pemberdayaan petani, maka sektor pertanian mampu memberikan keunggulan komparatif dan sekaligus semakin memberikan citra yang baik bagi petani (RPJM DESA). Upaya pemerintah, khususnya Kementrian Pertanian, dalam meningkatkan produksi pangan pokok strategis, yakni beras, menuai hasil yang menggembirakan. Hal ini dibuktikan dengan data yang dirilis Badan Pusat Statistik (BPS), angka sementara produksi padi 2020 sebesar 55,16 juta ton GKG (Gabah Gering Giling), atau setara dengan dengan 31,63 juta ton beras. Produksi padi pada 2020 ini lebih tinggi dari pada produksi padi 2019. Peningkatan produksi padi 2020 ini disebabkan peningkatan luas panen sebesar 108.930 hektar atau naik 1,02\% menjadi 10,79 juta hectare. Sebaliknya, produktivitas padi relative sama dengan tahun lalu sekitar 5,1 ton/hectare (ha). Produksi itu dicapai berkat semangat 14 juta keluarga petani padi yang terus giat berusaha padi di tengah pandemic. Ini merupakan berita baik di tengah anggaran Kementrian Pertanian yang dipotong $\mathrm{Rp} 7$ trilliun, untuk mengatasi pandemic COVID-19, dan juga tantangan kondisi COVID-19 itu sendiri. Pada laporan BPS, juga 
diuraikan bahwa ada 22 provinsi yang perumbuhan produksinya positif dan bahkan $10 \mathrm{di}$ antaranya mengalami pertumbuhan di atas 7\% jika dibandingkan dengan 2019 (https://mediaindonesia.com ).

Salah satu kendala utama dalam usaha tani padi sawah di beberapa Kabupaten di Jawa Timur adalah keterbatasan tenaga kerja terutama tenaga kerja panen padi. Kelangkaan tenaga kerja panen padi menyebabkan jadwal tanam sering mundur/tidak tepat waktu, sehingga berpengaruh terhadap indeks pertanaman padi, serta gangguan (Organisme Pengganggu Tumbuhan) OPT yang akhirnya berpengaruh terhadap produksi padi. Oleh karna itu akan diadakan thresher yang membuat petani lebih cepat proses panennya dari pada sebelumnya (Tota Suhendrata. 2015). Munculnya permasalahan yaitu menyangkut hasil panen padi yang masih menggunakan alat perontok non mekanis yang masih bersifat tradisional dan manual. Dengan adanya kontur tanah sawah yang tidak merata dan tidak sedikit pula yang kontur tanahnya berundak ataupun terasering dan rawa, menyulitkan petani dalam membawa alat perontok padi yaitu dengan cara dipanggul oleh 2 orang untuk sampai di sawah dan cara menggunakan mesin masih dengan mengayuh pedal layaknya sebuah sepeda. Secara tradisional kegiatan perontokan padi akan menghasilkan susut tercecer yang relatif besar, mutu yang kurang baik dan belum rontok secara menyeluruh, membutuhkan tenaga yang cukup melelahkan dan membutuhkan waktu yang cukup lama sehingga tidak efisien (Rofikha Nuriyanti, 2019).

Power thresher ini merupakan alat perontok padi yang lebih cangih dari pada thresher yang manual seperti menggunakan pukulan, pancatan dan ada yang menggunakan mesin tetapi menggunakan mesin akan menimbulkan tumpukan sebagian gabah yang iya masukan kedalam thresher tersebut. Maka disitulah masih merugikan/mengurangi harga padi yang di panen tersebut (Radi Wallubi SY. 2018). Power thresher merupakan mesin prontok padi prinsip kerja dari mesin ini yaitu memisahkan gabah dan jerami dengan cara memotong jerami hingga ukuran yang kecil agar gabah dapat terpisah. Untuk meningkatkan efesiensi kegunaan mesin power thresher dapat di modifikasi dengan cara mengubah menjadi mata pisau untuk proeses pencacahan. Dalam kegiatan pencacahan kecepatan putar pisau sangat berpengaruh terhadap tingkat kehalusan pada bahan baku yang digunakan. Kecepatan putaran pisau 1500 rpm diperoleh hasil cacahan yang cukup baik yang dapat terpotong mencapai $100 \%$ dengan panjang potongan bervariasi mulai dari $2 \mathrm{~cm}$ hingga $6 \mathrm{~cm}$ (Muhammad Hamzah, 2020).

Sebelum proses pemanenan, dilakukan pengeringan sawah selama 7-10 hari sebelum masa panen dengan menggunakan sabit tajam untuk memotong pangkal batang, kemudian hasil panen di simpan pada suatu wadah atau tempat yang dialasi". Proses pemanenan dengan menggunakan tenaga mesin akan menghemat waktu, dengan alat thresher otomatis pemanenan dapat dilakukan selama 15 jam untuk setiap hektar, sedangkan dengan thresher 
otomatis pemanenan hanya dilakukan selama 6 jam untuk 1 hektar sawah (A. Irianto, 2008). Pada dunia teknologi ini teknik mesin tidaklah terlepas dari keberadaan suatu alat dan mesin yang berperan penting dalam kehidupan sehari-hari seperti mesin pertanian (Agus Setiawan, 2020). Rendahnya penerapan teknologi budidaya terlihat dari besarnya kesenjangan potensi antara produksi dari hasil penelitian dengan hasil di lapangan yang diperoleh oleh petani”. Hal ini disebabkan karena pemahaman dan penguasaan penerapan paket teknologi baru yang kurangdipahami oleh petani secara utuh sehingga penerapan teknologinya kurang efisien (Yusdha, et al, 2010).

Dampak pandemi COVID-19 saat ini melanda dunia termasuk Indonesia, sehingga menimbulkan berbagai dampak termasuk sektor pertanian (Yenti Sumarni, 2020). Terpuruknya perekonomian masyarakat akibat pandemik COVID-19 terjadi pula pada para petani padi dalam melakukan hasil panennya. Banyak petani tidak mematuhi protokol kesehatan COVID-19 seperti 3M (mencuci tangan, mememakai masker dan menjaga jarak), terutama saat proses panen. Kegiatan panen padi berkerumunan dan tidak menjaga jarak, tentunya hal tersebut dapat meresahkan masyarakat setempat yang dapat menimbulkan terpapar virus corona karena tidak mematuhi protokol kesehatan. Di samping itu dengan banyaknya pekerja dalam melakukan panen membutuhkan biaya yang cukup banyak, dan alat yang digunakan untuk penen padi tersebut masih menggunakan alat yang manual, sehingga membutuhkan waktu yang cukup lama. Maka dari itu, untuk menangani ketiga masalah tersebut dan memberikan kemudahan kepada petani dalam melakukan panen padi dan meningkatkan perekonomian petani di masa pandemi dibutuhkan suatu teknologi yang dapat membantu yaitu thresher padi otomatis. Mesin thresher (perontok) padi adalah bagian penting dari proses pengolahan beras, karena proses perontokan dan mesin yang digunakan untuk merontokkan gabah. Penerapan teknologi tersebut hanya membutuhkan satu operator dalam merontokkan padi, secara otomatis tidak menimbulkan kerumunan, sistem lebih canggih dari manual sehingga lebih cepat selesai dan menghemat biaya dan waktu. Sehingga dapat meningkatkan taraf perekonomian petani padi. Tujuan dari pelaksanaan kegiatan program kemitraan masyarakat (PKM) ini adalah mengimplementasikan mesin thresher padi otomatis untuk mengembangkan potensi ekonomi petani Desa Opo-opo di masa pandemic COVID-19 untuk memutus rantai virus COVID-19 dalam mencegah kerumunan waktu panen. 


\section{METODE PELAKSANAAN}

Adapun metode penelitian yang akan dilakukan pada kegiatan program kemitraan masyarakat (PKM) meliputi beberapa tahapan, diantaranya :

1. Penelitian Awal

Pada penelitian awal dilakukan observasi kepada para petani di Desa Opo-opo padi waktu panen di masa pandemic COVID-19 saat ini.

2. Perumusan Masalah dan Tujuan Penelitian

Dari penelitian awal maka rumusan masalah dan tujuan penelitian adalah membantu para petani untuk mengembangkan potensi ekonomi petani di masa pandemi COVID-19. Adapun rumusan masalah pada penelitian ini adalah mengimplementasikan untuk pengembangan potensi ekonomi petani pada masa pandemi COVID-19 ini dalam mencegah kerumunan waktu panen padi untuk memutus rantai virus COVID-19, maka secara otomatis tujuan penelitian ini adalah meningkatkan taraf ekonomi petani di masamasa susah saat ini yang ada di Desa Opo-opo.

3. Pengumpulan Data

Pengumpulan data berfokus pada kegiatan petani waktu panen padi agar tidak menimbulkan kerumunan, sistem lebih canggih dari manual sehingga lebih cepat selesai dan menghemat biaya dan waktu. Sehingga dapat meningkatkan taraf perekonomian petani padi di Desa Opo-opo.

4. Perancangan Mesin Theser Padi Otomatis

Tahap perancangan mesin thresher padi otomatis membutuhkan waktu yang cukup lama, karena proses perancangan dilakukan dengan memesan komponen, mendesaian, dan merancang mesin tersebut sesuai dengan kebutuhan petani padi pada waktu panen.

5. Implementasi Hasil Rancangan Mesin Thresher Padi Otomatis

Implementasi hasil mesin thresher padi otomatis untuk membantu petani di Desa Opo-opo dalam meningkatkan pengembangan taraf ekonomi petani dengan menggunakan teknologi pertanian, dan menghindari kerumunan pada waktu panen padi dalam memutus rantai virus COVID-19.

6. Pengujian Mesin Thresher Padi Otomatis

Pengujian mesin thresher padi otomatis dilakukan untuk mengetahui manfaat implementasi mesin thresher padi otomatis bagi petani padi di Desa Opo-opo di masa pandemi COVID-19 dalam mengembangkan perekonomian petani padi.

7. Kesimpulan

Penarikan kesimpulan ialah akhir setelah perancangan mesin thresher sudah rampung atau selesai, dan telah melewati uji coba dan perbaikan. Akan tetapi secara teknis kesimpulan bukan berarti selesai sepenuhnya, tapi mesin thresher akan terus diupdate dan kembangkan sesuai dengan tuntutan perubahan teknologi yang digunakan. 


\section{HASIL DAN PEMBAHASAN}

\section{Hasil}

Pelaksanaan kegiatan program kemitraan masyarakat (PKM) merupakan luaran dari Kuliah Kerja Nyata yang dilakukan oleh Dosen dan Mahasiswa Universitas Nurul Jadid Jurusan Teknik Elektro dengan judul Pkm Pemperdayaan Petani Padi Untuk Meningkatkan Ekonomi Pertanian Melalui Implementasi Mesin Thresher Di Desa Opo-Opo Selama Masa Pandemi COVID 19. Adapun beberapa kegiatan yang telah dilakukan adalah sebagai berikut:

1. Perumusan Masalah dan Tujuan Penelitian

Perumusan Masalah dan Tujuan Penelitian dilakukan oleh tim pelaksana dan mitra tentang solusi permasalahan yang ada di Desa Opo-Opo terkait pertanian. Ternyata yang terjadi di lapangan banyak para petani waktu panen padi masih tidak mengindahkan protokol kesehatan dan terjadi kerumunan untuk memutus rantai virus COVID-19 yang sudah ditegaskan oleh SATGAS COVID-19 yg berada di Desa Opoopo.

2. Pengumpulan Data

Pengumpulan data berfokus pada mencari info dari para petani waktu panen dan informasi dari perangkat Desa Opo-opo sebagai mitra kegiatan program kemitraan masyarakat (PKM.

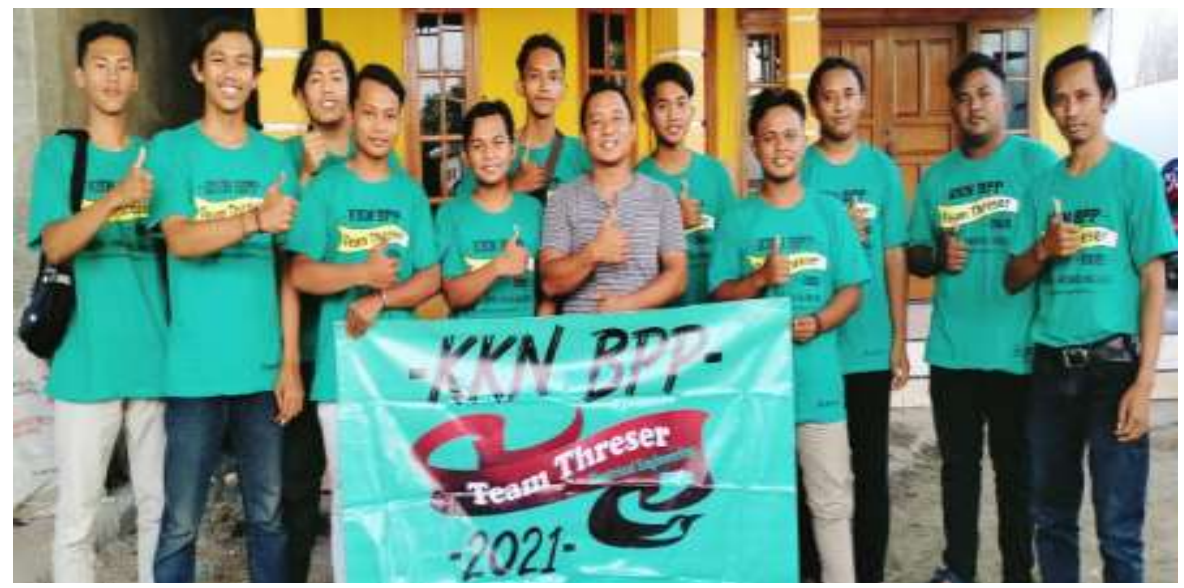

Gambar 1. Koordinasi dengan mitra perangkat Desa Opo-opo

3. Perancangan Mesin Theser Padi Otomatis

Tahap perancangan mesin thresher padi otomatis yang akan digunakan dalam PKM di Desa Opo-opo dilakukan dalam beberapa tahapan, yaitu ;

a. Perancangan Rangka dan Control Threser

Dalam perancangan mesin thresher otomatis dilakukan melalui 2 pengerjaan yaitu, perancangan mekanik dan perancangan elektrikal. 
b. Finishing Mesin Threser

Setelah peracangan mekanik dan elektrikal selesai, maka selanjutnya akan dilakukan finishing mesin thresher untuk bisa dapa di implementasikan ke lapangan bersama para petani yang berada di Desa Opo-opo Kecamatan Krejengan Kabupaten Probolinggo.

4. Implementasi Hasil Rancangan Mesin Thresher Padi Otomatis

Implementasi hasil rancangan mesin thresher digunakan untuk petani di Desa Opoopo dalam memanen padi untuk meningkatkan ekonomi petani dimasa pandemi Covic 19.

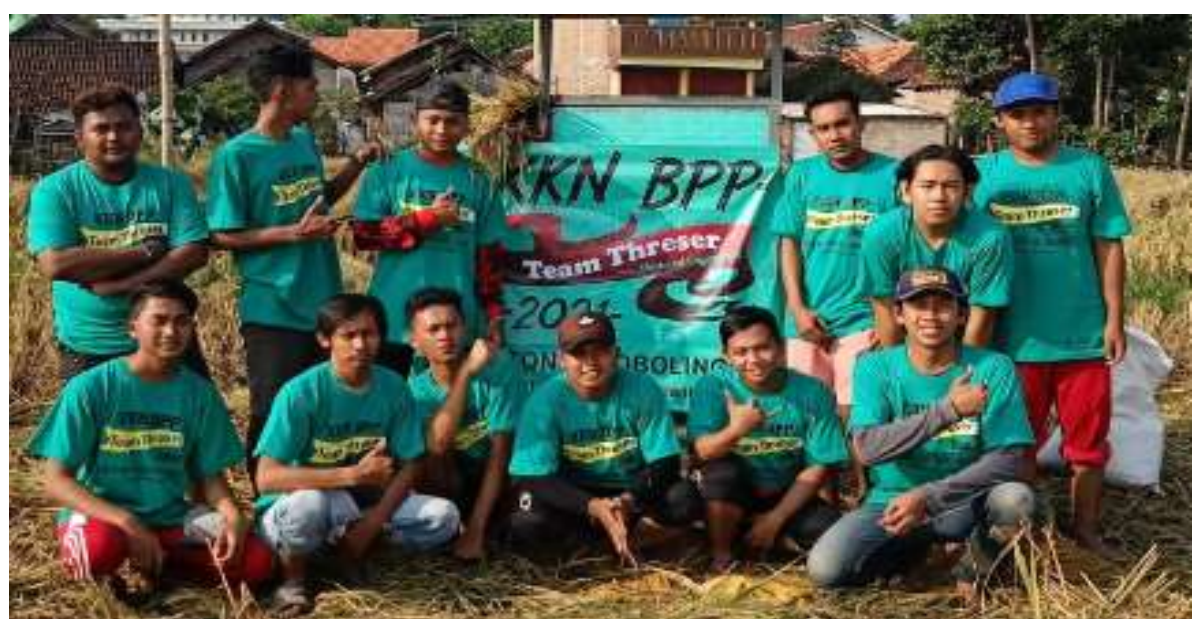

\section{Gambar 2. Implementasi Mesin Threser}

5. Pengujian Mesin Thresher Padi Otomatis

Pengujian mesin thresher padi otomatis dilakukan setelah proses perancangan selesai dan siap untuk digunakan. Pengujian mesin tersebut dilakukan oleh petani di Desa Opo-opo yang sudah berpengalaman dalam hal menggunakan thresher agar dapat dinilai dan dikoreksi sehingga akan dilakukan evaluasi.

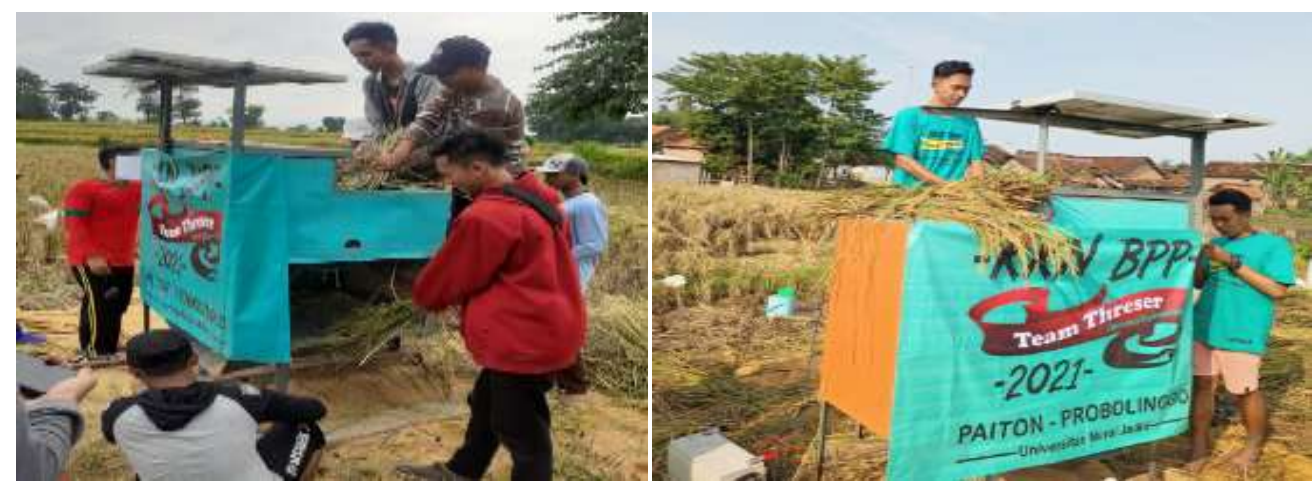

Gambar 3. Pengujian Mesin Mesin Threser 
Tabel 1. Hasil Perontokan Gabah

\begin{tabular}{ccccc}
\hline No & $\begin{array}{c}\text { Luas Lahan } \\
\left(\mathrm{m}^{3}\right)\end{array}$ & $\begin{array}{c}\text { Berat Gabah } \\
(\mathrm{kg})\end{array}$ & $\begin{array}{c}\text { RPM } \\
\text { Motor DC }\end{array}$ & $\begin{array}{c}\text { Tegangan } \\
(\mathrm{V})\end{array}$ \\
\hline 1 & 150 & 1000 & 106.2 & 10 \\
2 & 200 & 1600 & 32.10 & 9 \\
3 & 220 & 1800 & 35.7 & 9 \\
\hline
\end{tabular}

\section{Pembahasan}

Mesin threser otomatis ini menggunakan tenaga panas mataahari (solar cell), yang mana dapat digunakan oleh petani di Desa Opo-opo Kecamatan Krejengan Kabupaten Probolinggo untuk memanen padi agar dapat meningkatkan hasil panen padinya, serta dapat menghindari kerumunan dalam hal panen yang mana telah dicanangkan oleh pemerintah untuk menghidari memutus rantai virus COVID-19 yang sudah ditegaskan oleh SATGAS COVID-19. Mesin threser otomatis mempunyai kelebihan dan kekurangan dalam merontokkan padi 1000-1800 per jam, dengan luas lahan antara $150 \mathrm{~m}^{3}-220 \mathrm{~m}^{3}$, dengan putaran motor $106.2 \mathrm{~S}-35.7 \mathrm{~S}$, dan dapat dilakukan dengan 1 operator saja.

Dampak dari penggunaan mesin threser otomatis terhadap petani padi di Desa Opoopo yaitu, 1). Dilihat dari segi efisiensi waktu yang dibutuhkan pada waktu panen lebih efisiensi dari pada menggunakan mesin treseher konvensional, dimana waktu yang dibutuhkan dengan menggunakan mesin thresher padi otomatis hanya memerlukan waktu 1 2 jam, 2). Dari segi biaya petani pada waktu panen memerlukan biaya yang relatif lebih irit dari pada menggunakan mesin thresher padi konvensional, karena kalau menggunakan mesn thresher padi otomatis hanya menggunakan 1 operator, dari pada mesin thresher padi yang menggunakan 2 sampai 3 operator, 3). Dapat meningkatkan perekonomian para petani padi dimasa pandemi covoc-19 teruama di Desa Opo-opo.

Pelaksanaan kegiatan program kemitraan masyarakat (PKM) merupakan luaran dari Kuliah Kerja Nyata yang dilakukan oleh Dosen dan Mahasiswa Universitas Nurul Jadid Jurusan Teknik Elektro, sebagai kegiatan pengenalan mesin threser otomatis untuk petani di Desa Opo-opo Kecamatan Krejengan Kabupaten Probolinggo, dalam meningkatkan hasil panennya dan pengenalan teknologi untuk mengetahui tentang perawatan dan penggunaan mesin threser otomatis secara efisien dan efektif. Manfaat dari Pelaksanaan kegiatan program kemitraan masyarakat (PKM) ini adalah untuk peningkatan ekonomi pertanian, terutama meminimalisir kerugian dalam biaya pasca panen di Desa Opo-opo Kecamatan Krejengan Kabupaten Probolinggo di masa pandemi COVID-19.

\section{KESIMPULAN}

Dari pemapaparan hasil dan pembahasan diatas, dapat ditarik kesimpulan bahwasanya program dari kegiatan program kemitraan masyarakat (PKM) adalah untuk meningkatan hasil pertanian di Desa Opo-opo di masa pandemi Covic-19, dimana hasil dari perontokkan padi 1000-1800 per jam, dengan luas lahan antara $150 \mathrm{~m}^{3}-220 \mathrm{~m}^{3}$, dengan 
putaran motor 106.2 S - 35.7 S, dan kebermanfaatan dari program PKM ini adalah untuk meminimalisir kerugian dalam biaya pasca panen, dan pengenalan teknologi pertanian kepada petani di Desa Opo-opo.

\section{DAFTAR PUSTAKA}

Agus Setiawan, Untung Surya Dharma, Eko Budiyanto. 2020. "Pengaruh jenis bahan dan jumlah gigi perontok terhadap kinerja mesin thresher sebagai perontok padi ". Vol 1, No 1. Artikel Teknik Mesin dan Manufaktur (ARMATUR). ISSN (online) : 2722-0796. ISSN (cetak) : 2722-080x.

Agus Suharmanto, Suwahyo, Sunyoto. 2016. "Pemberdayaan Masyarakat Melalui Penerapan Mesin Perontok Padi (Power Thresher) Bagi Petani Di Desa Kenteng, Kecamatan Bandungan". Rekayasa : Jurnal Penerapan Teknologi dan Pembelajaran. Vol 18, No 2 (2020). p-ISSN 0216-6631 e-ISSN 2527-6964

A. Irianto, "Modifikasi Teknik Pemanenan," Medan: Dinas Pertanian Sumatera Utara, 2008.

https://mediaindonesia.com/opini/358366/produksi-padi-2020-dan-peluang-peningkatannyake-depan

Muhammad Hamzah, 2020. "Pengaruh Kecepatan Putaran Pisau Dan Kondisi Bahan Terhadap Kinerja Power Thresher Modifikasi Pada Proses Pencacahan Ampas Tebu". Program Studi Teknik Pertanian Jurusan Teknologi Pertanian Fakultas Pertanian Universitas Sriwijaya 2020.

Radi Wallubi SY. 2018. "Modifikasi Alat Perontok Padi (Power Thresher) Menjadi Alat Pencacah Jerami". Skripsi Program Studi Teknik Pertanian Jurusan Teknologi Pertanian Fakultas Pertanian Universitas Sriwijaya, 2018.

Rencana Pembangunan Jangka Menengah Desa (RPJM -DESA) TAHUN 2016 - 2021. DESA OPO-OPO KECAMATAN KREJENGAN KABUPATEN PROBOLINGGO.

Rofikha Nuriyanti, Linda Kurnia Supraptiningsih. 2019. "PKM Mesin Power Thresher : Solusi Ketahanan Pangan Bagi Petani Di Kabupaten Probolinggo". J-ADIMAS (Jurnal Pengabdian kepada Masyarakat) Volume 1, Nomor 1, Juli 2019: 46 - 50.

Tota Suhendrata. 2015. "Pengembangan Penerapan Mekanisasi Pada Usaha Tani Padi Sawah Melalui Pemberdayaan Kelembagaan Petani: Studi Kasus Di Desa Ngarum, Kabupaten Sragen, Jawa Tengah". Balai Pengkajian Teknologi Pertanian Jawa Tengah. pse.litbang.pertanian.go.id.

Yenti Sumarni, 2020. "Pandemi Covic-19: Tantangan Ekonomi Dan Bisnis". Jurnal Ekonomi dan Perbankan Syariah (Al-Intaj), Vol. 6 No. 2 September 2020.

Yusdha, et al. Ciranti Akriana, Jakarta: Erlangga, 2010. 